\title{
Recalibrating the State of the Union
}

Visual Rhetoric and the Temporality of Obama's Neoliberal Economics in the 2011 Enhanced State of the Union Address

James Alexander McVey

University of North Carolina Chapel Hill

Poroi 11,2 (December 2015)

Keywords: Temporality, economics, neoliberalism, visual rhetoric, presidential rhetoric

In the face of a still-stalling economic recovery, President Barack Obama's 2011 State of the Union Address called on Americans and members of Congress to reinvest in the nation's attempt to "Win the Future," focusing on the President's goal of restoring America's economic competitiveness. For the first time in the history of the address, the 2011 State of the Union was accompanied online by an enhanced version, which gave viewers the option of experiencing the speech alongside a display providing images, charts, graphs, outlines, and data visualizations (Obama, 2011).

This paper examines the visual rhetoric of the 2011 enhanced State of the Union, locating this rhetoric in an aesthetic regime of neoliberal temporality. I argue that the visual rhetoric of the enhanced address positions itself between conservative and progressive temporalities in order to promise a future economic victory prefigured by the economic logics of the past. Working between Svetlana Boym's understanding of a restorative nostalgia that seeks to return to a lost, mythic origin, and a reflective nostalgia which looks to the past to open up new possibilities for the future, I argue that the temporal rhetoric of neoliberalism stylizes the return to the past as modality of progression in the future. I draw on the work of Lauren Berlant and Sarah Sharma to argue that the aesthetics of the enhanced State of the Union invites viewers into a recalibrative nostalgic temporality that works reciprocally between restoration and reflection, allowing viewers to adjust their relationship to a deflated political scene without 
fundamentally altering the political coordinates that produce the conditions of economic exchange.

Whereas Obama's turn to the future offers some hope for progressive adjustment in democratic temporalities, the nostalgic frame in which Obama situates this (re)turn effaces these possibilities by determining in advance the historical, competitive mode of American free-market economics through which victory can be attained. The Enhanced 2011 State of the Union offers viewers an unproblematic movement between nostalgia and futurity, working rhetorically to transcend debates about the values of the past while simultaneously calling on audiences to invest their energies in political deliberations about the present and the future. The Enhanced 2011 State of the Union is thus an important case study for understanding the relationship between visual rhetoric, aesthetics, and time in presidential speech.

The paper unfolds in three sections. In the first, I discuss the relationship between nostalgia, time, and rhetoric. I outline Boym's distinction between restorative and reflective nostalgia and demonstrate how that distinction is mirrored in rhetorical studies' treatment of conservative and liberal temporal rhetorics. I then problematize that distinction by offering recalibrative time as a new modality of neoliberal subjectivity. Recalibrative nostalgia is neither exclusively reflective nor entirely restorative, but instead relies on both registers to recalibrate citizen's relationship to time. This recalibration, I argue, constitutes a cruelly optimistic relationship to the political scene, insofar as it invests a return to the deflated politics of the past with the energies of a progressive hope in the future. In the second section I engage in a close reading of the 2011 State of the Union address. I track how a recalibrative temporality emerges throughout the address as its (primarily visual) rhetorics labor to move the audience seamlessly from nostalgia to futurity, constituting a new mode of adjustment to the political scene, a new way of feeling political. Finally, in the conclusion, I discuss how this form of adjustment works toward a recalibrative aesthetic experience of cruel optimism and discuss the implications of this for our understanding of the visual rhetoric of Presidential public address.

\section{From Nostalgia to Futurity - Neoliberalism's Recalibrative Temporalities of Cruel Optimism}

Svetlana Boym defines nostalgia as a type of "historical emotion," one constituted by "a longing for a home that no longer exists or has never existed" (Boym, 2007, 8, 7). Nostalgia is a particular 
aesthetic and affective modality, a means of distributing sensibility and defining the contours of perception. Boym goes so far as to call nostalgia a means of colonizing subjectivity, arguing that, "Nostalgia produces subjective visions of afflicted imagination that tend to colonize the realm of politics, history, and everyday perception" (Boym, 2007, 9). Because it is related to the longing for a home and because this longing for a home works to colonize our understanding of politics, history, and perception, nostalgia has an important role to play in political visions of nationalism. Nostalgia stitches the individual to the collective or national. As Boym writes, "Nostalgia is about the relationship between individual biography and the biography of groups or nations, between personal and collective memory" (Boym, 2007, 9). Nostalgia thus offers an affective relay between the individual's memory and the nation's history.

Nostalgia is especially well suited to discourses of exceptionalism. National exceptionalism, especially in the American context, blends the particularities of the nation with its universal aspirations. It identifies the specific ideals of American democracy with the universal telos of human accomplishment that they represent. The exceptional is the particular that tends toward a universalization of its own particularity. Nostalgia's affects thus labor toward a simultaneous longing for the homeland and a projection of the homeland onto a horizon of universality. Boym writes:

Modern nostalgia is paradoxical in the sense that the universality of its longing can make us more empathetic towards fellow humans, and yet the moment we try to repair that longing with a particular belonging-or the apprehension of loss with a rediscovery of identity and especially of a national community and unique and pure homeland-we often part ways with others and put an end to mutual understanding (Boym, 2007, 9).

The paradoxes of nostalgia's universality also speak to the ethical paradoxes of American exceptionalism. The ethical paradox of American exceptionalism is what Russell Lowell Riley identifies as the dilemma of America's lasting historical "dissonance between a creed of equality and customs of inequality" (Riley, 1999, x). Nostalgia works to reproduce the vision of lost national ideals, even in the face of historical crises that prevent those ideals from flourishing in the present.

Yet, despite the tendency for nostalgia to problematically reproduce a longing for the past, nostalgia can also be a mechanism 
for the production of new futures. As Boym writes, "Nostalgia... is not always retrospective; it can be prospective as well. The fantasies of the past, determined by the needs of the present, have a direct impact on the realities of the future" (Boym, 2007, 8). It is nostalgia's inherent possibility for altering our relationship to the future that holds allows Boym to see some ethical potential in nostalgia's affective labor. Nostalgia may tend to colonize perception, but it can also help productively and progressively redirect that perception to new futures. This ethical potentiality of nostalgic futurity lies in the distinction Boym draws between restorative and reflective forms of nostalgia. Restorative nostalgia looks exclusively to the past and wants to return to the lost homeland. Reflective nostalgia looks to the past as a way of understanding the present for the crafting of new futures. It seeks not to reproduce the past or return to a lost origin but to draw from the past ethical lessons that can teach us about the future:

Restorative nostalgia does not think of itself as nostalgia, but rather as truth and tradition. Reflective nostalgia dwells on the ambivalences of human longing and belonging and does not shy away from the contradictions of modernity. Restorative nostalgia protects the absolute truth, while reflective nostalgia calls it into doubt (Boym, 2007, 13).

In short, restorative nostalgia is a conservative temporal mode, whereas reflective nostalgia is a progressive temporal mode. For Boym, this distinction between reflective and restorative nostalgia is a sharp dichotomy, defining two entirely different relationships to temporality: "Restorative and reflective nostalgia might overlap in their frames of reference but do not coincide in their narratives and plots of identity. In other words, they can use the same triggers of memory and symbols... but tell different stories about it" (Boym, $2007,15)$. Thus while both modes of nostalgia offer a certain relationship to the past their temporal orders are separated by a vast narrative gulf, and never the twain shall meet.

Rhetorical scholars have established a similar distinction between conservative and progressive temporal rhetorics. As John M. Murphy notes, the rhetoric of American civil religion usually takes one of two distinct temporal forms: one conservative and one liberal. The conservative variant relies on the "language of Being, of eternal principles, of religion, tradition, and authority." The liberal variant relies on the "language of Becoming, of change" (Murphy, 2008, 43). Celeste Condit describes a similar use of conservative temporal rhetorics in President Richard Nixon's infamous "Checkers Speech." What defines Nixon's temporal conservatism is 
a "transcendent, permanent standard," which obfuscated the possibility of more progressive temporalities insofar as it "replaced a deliberative orientation, that is, an orientation toward the future" (Condit, 1989, 231). This understanding of conservative temporality as rhetorically constituted through tradition and eternality and progressive temporality as rhetorically constituted through change and futurity closely mirrors Boym's distinction between restorative and reflective nostalgia. Restorative nostalgia is "politically manipulated through newly recreated practices of national commemoration with the aim of re-establishing social cohesion, a sense of security, and an obedient relationship to authority" (Boym, 2007, 14). Reflective nostalgia, on the other hand, "is concerned with historical and individual time, with the irrevocability of the past and human finitude. Re-flection means new flexibility, not the reestablishment of stasis" (Boym, 2007, 15). However, this distinction between political temporal modes has increasingly become unstable.

Melanie Loehwing argues that the dichotomy between eternally oriented conservative temporalities and future oriented progressive temporalities has blurred in the political matrix of neoliberal subjectivity. The neoliberal citizen-subject is now constituted through discourses that seek to ensure the security of subjects in the present so that they may participate in the futurity of neoliberal subjectivity. Loehwing argues that the norms of democratic citizenship work to construct economically self-reliant and futureoriented neoliberal citizens based on their ability "to occupy the future-oriented perspective that transforms isolated individuals into communally minded democratic citizens" (Loehwing, 2010, 397). Under neoliberalism, the distinctions between conservative and liberal temporalities begin to blur, causing these formerly distinct temporal modes to blur into a zone of indistinction. Conservative economic reliance on the free market as the predetermined means of American economic success becomes politically stylized as a progressive means of accomplishing the American Dream.

Boym's distinction between reflective and restorative nostalgia falls into the same trap of rhetorical scholarship that assumes a binary between conservative and liberal accounts of time. Under neoliberalism, the lines between progressive and conservative discourse begin to blur and fold into one another. The contingent and the universal - being and becoming - become indistinguishable. This is what provides the rhetoric of American exceptionalism, the foundation of the "Washington Consensus" that defines the trajectory of global neoliberalism, with its Janus faced 
self-presentation. In an economy of neoliberalism, "new flexibility" of Boym's reflective nostalgia is nothing more than a code word for the "reestablishment of stasis," of Boym's restorative nostalgia. Neoliberalism calls on subjects both to actively orient themselves toward the future while simultaneously accepting the past trajectory of free market economics around which America's originary ideals set in motion. Subjects are called on to orient themselves towards the future in a productive fashion so that they may be properly competitive in the neoliberal market economy. Free market liberal economics represent the originary ideal of the great American democratic-capitalist experiment. In this way, it defines neoliberalism as the only acceptable future trajectory through a relationship to the values of the past.

If the dichotomy between restorative nostalgia and reflective nostalgia no longer serves as a useful theoretical heuristic for discussing temporality in modern conditions of neoliberal capital, we must seek out a new language for understanding the modes of temporal orientation operative in neoliberalism. Drawing on the work of Sarah Sharma, I call this new temporal orientation a form of "recalibrative nostalgia." Recalibration, Sharma argues, is the primary demand placed on neoliberal subjects: "Today, it is the expectation of all good subjects under contemporary capitalism to recalibrate, to find ways to keep up" (Sharma, 2011, 442). The idea of recalibration points toward a neoliberal temporality that does not require a conservative transcendence of agency but rather an investment of democratic agency into channels of neoliberal competition that, while carefully managed and limited in scope, are nevertheless open to deliberative intervention. As Sharma writes, "a deliberative recalibration is the expectation of all responsible selfgoverning citizens within late capitalism" (Sharma, 2011, 442). Neoliberalism does not require a conservative abandonment of hope for changing the future, but neither does it open up to a progressive transformation of the possibilities the future can offer. It requires the active participation and agential investment of neoliberal citizens, but does not require substantial transformation or deliberation about the neoliberal principles that define American exceptionalism.

Sharma's notion of recalibration has important resonances with Lauren Berlant's concept of adjustment. For Berlant, economic conditions under modern neoliberal capitalism produce a generalized sense of precarity which results in the fraying of fantasies of the good life:

The fantasies that are fraying include, particularly, upward mobility, job security, political and social 
equality, and lively durable intimacy. The set of dissolving assurances also includes meritocracy, the sense that liberal-capitalist society will reliably provide opportunities for individuals to carve out relations of reciprocity that seem fair and that foster life as a project of adding up to something and constructing cushions for enjoyment (Berlant, 2011, 3).

In the face of these fraying fantasies of the good life, subjects do not simply wither away and detach completely from the political scene, but rather adjust to it in an attempt to simply, in the words of Bob Dylan, “keep on keepin' on.” Berlant's work tracks the various affective modalities through which "adjustment to the loss of this fantasy" occurs under modern conditions of precariousness (Berlant, 2011, 11).

Specifically, Berlant is interested in a particular mode of adjustment that she names "cruel optimism." In the face of a political scene that has retreated behind a well-protected wall of special interests wherein political participation emerges as an entertainment spectacle rather than genuine political engagement in the political process, cruel optimism defines those modes of adjustment that encourage attachment to the political scene despite decreasing evidence of its lack of salience for everyday life or its capacity to produce political relations of reciprocity and democratic recognition. In the face of widespread political detachment produced by the general precariousness of neoliberal subjects that have been abandoned by neoliberal capitalism, maintaining the fantasy of the political requires adjustments and recalibrations in order to reattach subjects to the scene of the political. Despite the increasing inability of individual subjects to influence the realm of political affairs, adjustments must be made in order for those subjects to feel political:

[A]n intimate attachment to the political can amount to a relation of cruel optimism... [A]n optimistic attachment is cruel when the object/scene of desire is itself an obstacle to fulfilling the very wants that the people bring to it: but its life-organizing status can trump interfering with the damage it provokes. It may be a relation of cruel optimism, when, despite an awareness that the normative political sphere appears as a shrunken, broken, or distant place of activity among elites, members of the body politic return periodically to its recommitment ceremonies and scenes... All of these modes of orientation and having a feeling about it confirm our attachment to the system and thereby 
confirm the system and the legitimacy of the affects that make one feel bound to it, even if the manifest content of the binding has the negative force of cynicism or the dark attenuation of political depression (Berlant, 2011, 227).

Attachment to the political in the face of its increasing inability to fulfill the fantasy of the good life constitutes a relationship of cruel optimism.

Cruel optimism is necessarily a temporal relationship. It looks forward to the future by maintaining the promise of the good life that has eroded in the present yet remains available as a form of nostalgic longing. Recalibrative nostalgia is a form of cruel optimism, insofar as it maintains that the fraying fantasies can be found in the originary ideals of the America's democratic experiment, so long as one actively doubles down on those ideals. This doubling down occurs through a recalibration of one's agency to the demands of the present, reinvesting in the feeling of the political scene despite the mountain of evidence that those feelings no longer lead to the reciprocal relations and promise of upward mobility that they had once guaranteed. Berlant calls on us to track the "patterns of adjustment" that constitute cruelly optimistic relations "in specific aesthetic and social contexts" (Berlant, 2011, 9). This is the task of the next section, as I track the modes of adjustment and attachment to the scene of the political offered by the 2011 enhanced version of the State of the Union Address.

\section{The Enhanced State of the Union}

The enhanced State of the Union address was made available both on Youtube and on the whitehouse.gov website. The address features a split screen. On the left hand side of the screen is the regular broadcast of the State of the Union, the same broadcast that was simultaneously aired live on national TV. On the right side of the screen is a sidebar containing a slide show, including various displays of information, photos, images, graphs, charts, and a series of captions, and organizing titles for each major section of the speech. Before the President began speaking, the live broadcast showed the President making the rounds in the Congressional chamber, shaking hands and greeting guests. While this was going on, the side bar contained trivia questions, such as "Which President delivered the first televised broadcast of the Address?" It also advised viewers to "Join in for Open For Questions right after the speech at whitehouse.gov/SOTU" (Obama, 2011). These two features demonstrate immediately the interactivity of the new "enhanced" address. 
As Obama begins discussing the challenges facing the American economy, the side panel displays a number of graphs showing a sharp drop-off in the economy before he took office and steady economic recovery after. Here, the graphs attempt to show that Americans have been set onto the path of recovery, yet, we are told, more recalibrations will be needed in order to continue this growth. When discussing the administration's previously enacted Payroll Tax Benefits, the side panel shows the average thousand dollar benefit that Americans will receive above a silhouette of a family of four. This generic American family invites the viewer to locate themselves and their own family in the picture, seeing themselves, the generic subjects of the political, as the direct beneficiaries of these adjustments.

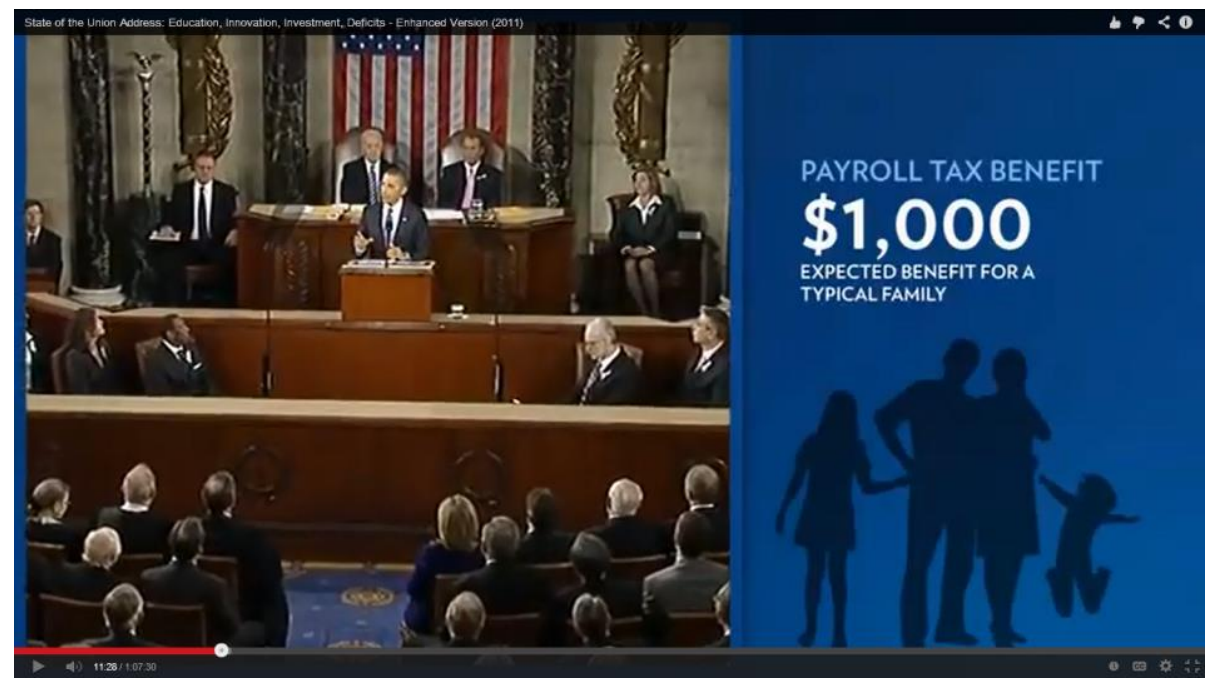

Figure 1: Screen capture of Enhanced State of the Union - Obama and Congress; "PAYROLL TAX BENEFIT \$1, OOO EXPECTED BENEFIT FOR A TYPICAL FAMILY"

Yet, the economic security of this generic American family is still under threat by generalized precariousness and the fraying of fantasy. Obama paints a nostalgic mental image, calling on Americans to remember a time when finding a job was as easy as showing up and being ready to work:

Many people watching tonight can probably remember a time when finding a good job meant showing up at a nearby factory or a business downtown. You didn't always need a degree, and your competition was pretty much limited to your neighbors. If you worked hard, chances are you'd have a job for life, with a decent paycheck and good benefits and the occasional promotion. Maybe you'd even have the pride of seeing your kids work at the same company (Obama, 2011). 
As Obama is painting this mental image, the side panel is blank, requiring the memory of the viewer alone to perform the aesthetic labor of nostalgic remembrance. The blank screen allows the viewer to make specific a generalized crisis, filling in their own particular memories and stories as exemplars of the broader structural crisis of neoliberal adjustment. Yet this mental image is suddenly interrupted, as Obama says, "That world has changed. And for many, the change has been painful. I've seen it in the shuttered windows of once booming factories and the vacant storefronts on once busy Main Streets" (Obama, 2011). This abrupt interruption inserts a sense of loss into the previous scene of American prosperity and upward mobility. The abruption occurs both in the short syntax of the sentence "That world has changed" and in the visual display on the side panel. That panel changes as soon as Obama says this sentence. From a blank blue field it changes to a graph showing a decline in real median household income.

This generalized sense of loss, we are given to understand, is not the result of particular policies, or a result of the economic failures of neoliberal economic philosophy and the accompanying destruction of the welfare state, but rather of "revolutions in technology" (Obama, 2011). The natural force of the free market which had originally set America on the path to victory has now changed the rules "in the middle of the game" (Obama, 2011). In the face of this changing economic landscape, accordingly, Obama calls on Americans not to fundamentally rethink the economic principles that have gotten them into this mess, but rather to adjust to the new rules of the game, declaring, "So, yes, the world has changed. The competition for jobs is real. But this shouldn't discourage us. It should challenge us" (Obama, 2011). Obama calls on Americans to invest their energies in this challenge, to recalibrate, to learn how to play the game better. The potential of Americans to win the future is already embedded in the very concept of America itself, we are informed, in the ideals of selfdetermination which make America an exceptional nation: "What's more, we are the first nation to be founded for the sake of an idea - the idea that each of us deserves the chance to shape our own destiny" (Obama, 2011). Here, the neoliberal rhetoric of opportunity labors to provide Americans an image of the vast historical potential of their own agency, seeing themselves as capable of changing the future and actively shaping their own destiny.

The take home message Obama provides for audiences is that by investing their energies in the political project of neoliberal adjustment Americans can achieve the glorious victory promised to 
them by the nation's originary exceptionalism. America is destined for victory, but it requires the labor of its citizens to get there: "The future is ours to win. But to get there, we can't just stand still" (Obama, 2011). Immediately following this call to action, Obama appeals to the memory of one of the landmark figures of American liberalism, RFK, a figure who represents for many Americans both the promise of youth and the tragic loss of the past. Obama declares, "As Robert Kennedy told us, 'The future is not a gift. It is an achievement.' Sustaining the American Dream has never been about standing pat. It has required each generation to sacrifice, and struggle, and meet the demands of a new age" (Obama, 2011). As he begins that quote, the side panel switches to a black and white image of Robert Kennedy, facing slightly to his right, sitting pensively with his right hand to his chin, presumably deep in thought about the policies that would help lead America forward on the path to prosperity and achievement. The black and white image is adorned with the quoted maxim from "Bobby Kennedy" in blue font hovering above his head. The image creates a powerful affective resonance, as Obama turns to his right and gestures with his right hand, briefly embodying the spirit of this iconic image of progressive hope. For a moment, the nostalgic longing for a past gone-by unites with the hope to which we aspire in the future. The loss of a great figure of progressive liberalism is resolved seamlessly in the body of the present day sovereign. Yet, the move from nostalgia to futurity is not yet complete.

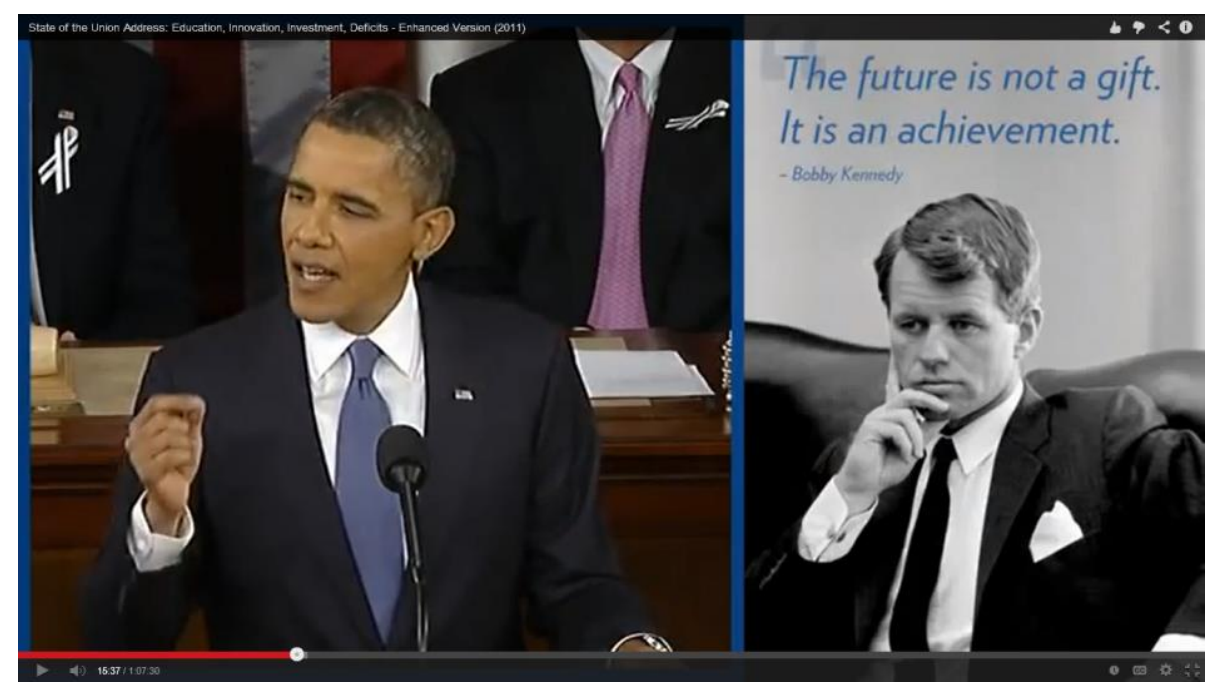

Figure 2: Screen capture of Enhanced State of the Union - Obama; Robert F. Kennedy

Obama declares, "And now it's our turn." As he says this, Obama turns to the viewer's right and the side panel switches from the black and white image of RFK to a glossy color image of Obama 
giving a speech at the General Motors Auto Plant in Hamtramck, Michigan. Obama is shown giving a speech from the back of a flatbed truck, pointing forcefully ahead, sleeves rolled up and jacket off. This is Obama the populist folk hero in action. The viewer is placed laterally to the scene, alongside a shiny car whose side view mirror points back, perhaps inviting the viewer to see themselves in the image. The picture is taken from a low angle rather than a direct face-on shot. The viewer is not meant to view this picture as a reproduction of the speech as it was originally seen, but rather to figure themselves as a part of the scenery. Directly across from the viewer is a crowd of onlookers, many pointing cameras at the president, and also, thus, at the viewer themselves. The viewer is intimately involved, almost part of the landscape that makes up this scene. Those who experience the enhanced State of the Union become part of the scene of the political. The enhanced version creates a unique opportunity for them to experience not just a political speech, but the experience of politics itself. By placing the viewer in this scene of political sentiment, the sense of nostalgia from the previous slide of the black and white image of RFK resolves itself not only into Obama's body, but into the body of the viewer who is affectively recalibrated to the scene of the political through their mere viewing of the enhanced version.

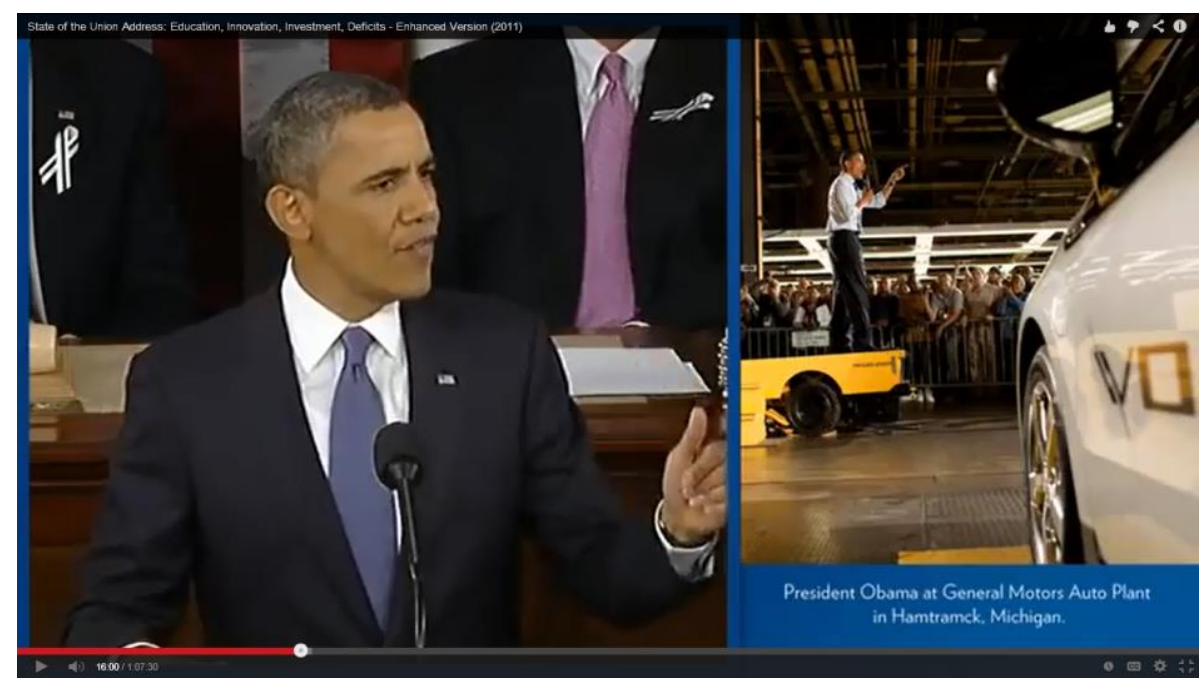

Figure 3: Screen capture of Enhanced State of the Union - Obama; Obama at General Motors Auto Plant

The rhetorical moves that occur in the content of the address, wherein victory is achieved not through a change in political philosophy but by recalibration of the political will to meet the demands of the updated rules of the neoliberal economic game, are mirrored in the form of the enhanced version. The viewer does not need to be political in any specific sense of the word, but is called on 
to feel political through watching of the address. Viewers both see the President gesturing forward as he delivers the State of the Union and simultaneously see themselves alongside Obama pointing ahead on the factory floor, issuing the command onward, upward, forward, out of the past and into the future. The rhetorical labor of the address is the movement from nostalgia to futurity, achieved not through any substantial deliberation over the process of progress but through an investment and attachment to the scene of the political. In this regard, the crises of the present are resolved not by any substantive change in political philosophy, but by an affective recalibration to partake in the political by aligning ourselves with images of those inspirational leaders who push us toward the fulfillment of our originary exceptional promise.

The labor of moving seamlessly from nostalgia to futurity is at work throughout the enhanced address. As Obama discusses the technological advancements necessary to "win the future," he again turns to the greatness of America's past to guide the movement into the future and calibrates this movement aesthetically through visual appeals. Just as the sophisticated use of this new electronic medium embodies the challenges of updating older genres of speech to the digital age, Obama appeals to the nation to rise to the challenges of the contemporary age by reinvesting their energies in new technological accomplishments. Obama recalls, "Half a century ago, when the Soviets beat us into space with the launch of a satellite called Sputnik, we had no idea how we would beat them to the moon. The science wasn't even there yet. NASA didn't exist" (Obama, 2011). As Obama calls on this challenge Americans faced in the past, the enhanced sidebar again contains a black and white image of a headline from the front page of the New York Times, reading "SOVIET FIRES EARTH SATELLITE INTO SPACE; IT IS CIRCLING THE GLOBE AT 18,00o M.P.H.; SPHERE TRACKED IN 4 CROSSINGS OVER U.S.” (Obama, 2011). Obama then transitions into the political recalibrations Americans had to make in the past to win the space race, saying, "But after investing in better research and education, we didn't just surpass the Soviets; we unleashed a wave of innovation that created new industries and millions of new jobs" (Obama, 2011). As Obama says this, the image switches to an iconic photo of an astronaut during the U.S. moon landing. Unlike the grainy, black and white headline from the preceding sidebar, this image is glossy and refined, with the red white and blue of the American flag popping off the space suit of the astronaut. One can even see a reflected image of another astronaut in the helmet of the pictured astronaut. Again, viewers are subtly called to see themselves in this reflection, to picture 
themselves within a scene of American accomplishment. The image occupies a liminal temporal zone between the past and the future. Space travel - traversing the last frontier - necessarily connotes a certain sense of futurity through the technological advancements required to achieve such a feat. Yet the iconic image of the moon landing also presents a type of nostalgia for a time of unquestioned American greatness. It is one of the defining iconic moments of American accomplishment, a sure sign that we have always been the exceptional nation destined to "win the future."

“This is our generation's Sputnik moment," Obama declares, again using short syntax to bring the listener back into the present through the abrupt punctuation in the speech's movement (Obama, 2011). The sidebar goes to the blank blue field as Obama begins to outline the policy details that connect his legislative agenda to this call for action in the present. He says, "Two years ago, I said that we needed to reach a level of research and development we haven't seen since the height of the Space Race. And in a few weeks, I will be sending a budget to Congress that helps us meet that goal. We'll invest in biomedical research, information technology, and especially clean energy technology" (Obama, 2011). As Obama says "clean energy technology," the sidebar changes to an image of Obama touring the DeSoto Next Generation Solar Energy Center in Arcadia, Florida. The picture is again shot from a low angle, showing Obama, without a jacket, sleeves rolled up, tie blowing in the wind, walking down a dirt path in a grass field with two workers from the facility. Behind him, the reflective surfaces of a series of solar panels shine against the partly cloudy daytime sky. The viewer is again placed alongside this scene of political action, almost as if located within the scene itself, watching it unfold as the President tours the facilities of economic advancement that will carry America into the future.

Obama then tells the story of Robert and Gary Allen, two brothers from Michigan who owned a roofing company. He invokes the trauma of past national wounds, describing how in the wake of the September $11^{\text {th }}$ attacks, they had volunteered workers from their company to help rebuild the Pentagon. However, the brothers, faced with the economic hardship of the great recession, almost had to close their factory. Yet with the help of government loans they were able to recalibrate their business model, using their factory to manufacture solar shingles. Obama invokes the words of one of the brothers, saying, "In Robert's words, 'We reinvented ourselves"” (Obama, 2011).

As Obama begins telling this story, the camera pans away from him toward the two brothers, who are sitting in the Congressional 
chambers listening to the speech. The camera stays focused on these two citizens throughout the duration of the story, as the sidebar of the enhanced version remains blank. When Obama says "We reinvented ourselves," the sidebar switches to an image of President Obama touring an alternative energy research lab at MIT. Obama is carefully studying a piece of equipment being shown to him by a bald man, presumably a scientist in the research lab. As this image is displayed on the sidebar, the camera stays focused on the two brothers for twenty second and then switches over to the President delivering the speech. Again, in the sidebar image, the viewer is placed in the scene, as the camera peers laterally over the reflective equipment that shines under the bright fluorescent lights of the laboratory. The effect is extraordinary. The viewer observes not only the president engaging directly with the technologies that America must invest in to compete with the future; he does so alongside an image of the types of citizens who have themselves adapted, with the help of government loans for high tech clean energy production, and recalibrated their business model to fit the conditions of the new economy. Overcoming the hardships of precariousness is difficult, but made immanently achievable through the recalibrative labor and investment of citizens like the Allen brothers, and through the political recalibrations offered by Obama's legislative initiatives.

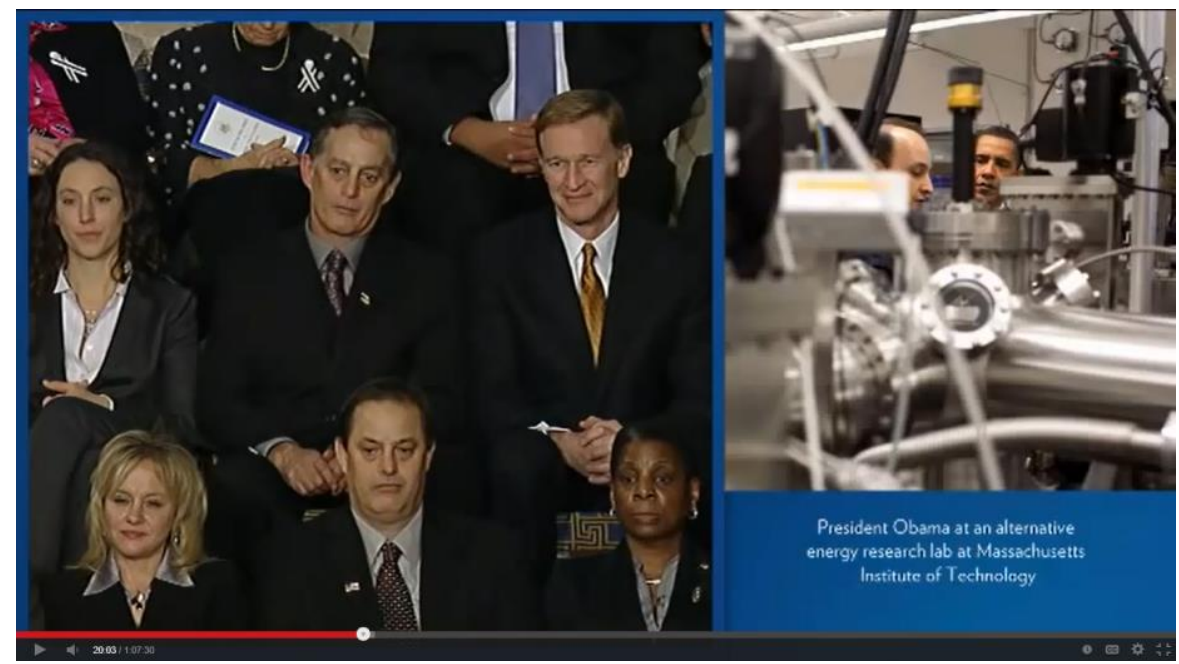

Figure 4: Screen capture of enhanced State of the Union - Robert and Gary Allen; Obama and scientist

Viewers who are watching this enhanced version and who, through its labor of purported interactivity, are called on to feel more immanently and intimately attached to the scene political, are provided the affective blueprint for such feelings in the image of these two average citizens who, through their recalibrative efforts, have become a model both for the types of adjustments Americans 
must strive towards and the types of political adjustments the administration offers through its legislative agenda. Both the labor of political recalibration and the particular agenda of the administration are represented synecdochically through these politically oriented bodies: Obama's body presented touring these various clean energy facilities and alternative energy laboratories, and the bodies of the two brothers sitting in the chambers of Congress.

However, the labor of this political attachment does not always occur seamlessly. Despite the attempt to depict the relay to the political scene as a smooth connection between the bodies of citizens and the promise of the political, the bodies of these citizens produce unpredictable affects. As the camera initially pans to the two brothers, the brother on the right (viewer's left) rolls his eyes, shakes his head, and mutters something seemingly under his breath. The brother on the left chuckles, and pats him on the knee, reassuring him. While the brother on the left maintains a grin throughout the time they are on camera, the brother on the right seems consistently nonplussed, forcing a slight smile that is thoroughly indistinguishable from a grimace. Near the end of their time on camera, the brother on the left seems to sense his brother's unease and pats him on the knee again, as the brother on the right shakes his head and again mutters something under his breath. A woman sitting to the right of the two brothers notices the disruption and glances over at them, pondering what's occurring next to her.

The moment is something of a visual hiccup in the smooth attachments to the political the scene attempts to display. A viewer playing very close attention may wonder what's on the brother's mind: Is he a Republican who disapproves of Obama, reluctantly attending the State of the Union at the invitation of the president as a matter of mere civic duty? Does he disapprove of his body being used as a political prop? Does he fear retribution for being attached to the image of a President so despised by many on the right? Or does he simply hate the attention brought on by being forced into the limelight, unaccustomed as he is to the visual drama of the political? The introduction of real bodies into the visual display of the scene of the political creates an inherent unpredictability in the relay of political attachments. The resonances may not transmit. The recalibration may be off. The intensities of political attachment may be disrupted by the affective intensities of boredom, interruption, displeasure, disgust, or distrust.

Yet this moment is ultimately fleeting. Like the demand of neoliberal adjustment itself, the viewers must learn to move beyond 
this temporary visual interruption, to put questioning of the past in the past and continue their inevitable march forward. The camera moves on. The speech proceeds. The disruptions, wounds, and traumas of the past are relayed into the progression of the future, as subjects recalibrate in the face of precarity and move on to the next challenge ahead of them. The next few slides from the enhanced sidebar are charts, graphs, and data displays outlining the details of the administration's energy plans. The messiness of possible disruption presented by bodies on display resolves into the supposed objectivity and neutrality of data presentation. This data presentation labors to locate the viewer of the enhanced version within the nitty-gritty details of policy analysis, attaching them to the political through their involvement in the logos of argumentative citizenship. The enhanced version thus moves back and forth between these moments of iconic nostalgia, present day political labor, and the promise of futurity. The enhanced version relays between human interaction and the visual display of data, relying on both the logic of sentiment and the sentimentality of logic, providing multiple modalities of attachment for citizens to connect themselves to the scene of the political, and multiple means of affective recalibration.

\section{Designing Recalibration - Design Aesthetics and the Visual Rhetoric of the Enhanced State of the Union}

The visual movement from nostalgia to futurity recurs throughout Obama's speech, ensconced in the visual rhetoric of the Enhanced State of the Union. Many times black and white images from one slide resolve into slick color images in the present, usually showing Obama at a workplace, school, research laboratory, or political gathering. They are surrounded by data displays, charts, figures, and graphs highlighting the economic problems of the past, the benefits of the administration's previous legislative initiatives, and the details about his future current proposals. The movement from nostalgia to futurity is played out throughout the varied visual rhetorics of the enhanced State of the Union. However, they frequently occur in even more subtle ways than those discussed above.

As Obama moves through his outline of legislative proposals, each set of proposals is given a theme in order to organize and punctuate the speech: Innovation, Education, Rebuilding, Responsibility, and Reform. When Obama first moves from each theme to another, a new side appears in the sidebar, displaying the words "WINNING the FUTURE" in a serif font, and the name of the 
theme in sans serif font (Obama, 2011). Despite the innocuous nature of this appeal, these images are themselves subtle visual cues that signal the movement from a nostalgic past into the victory of the future.

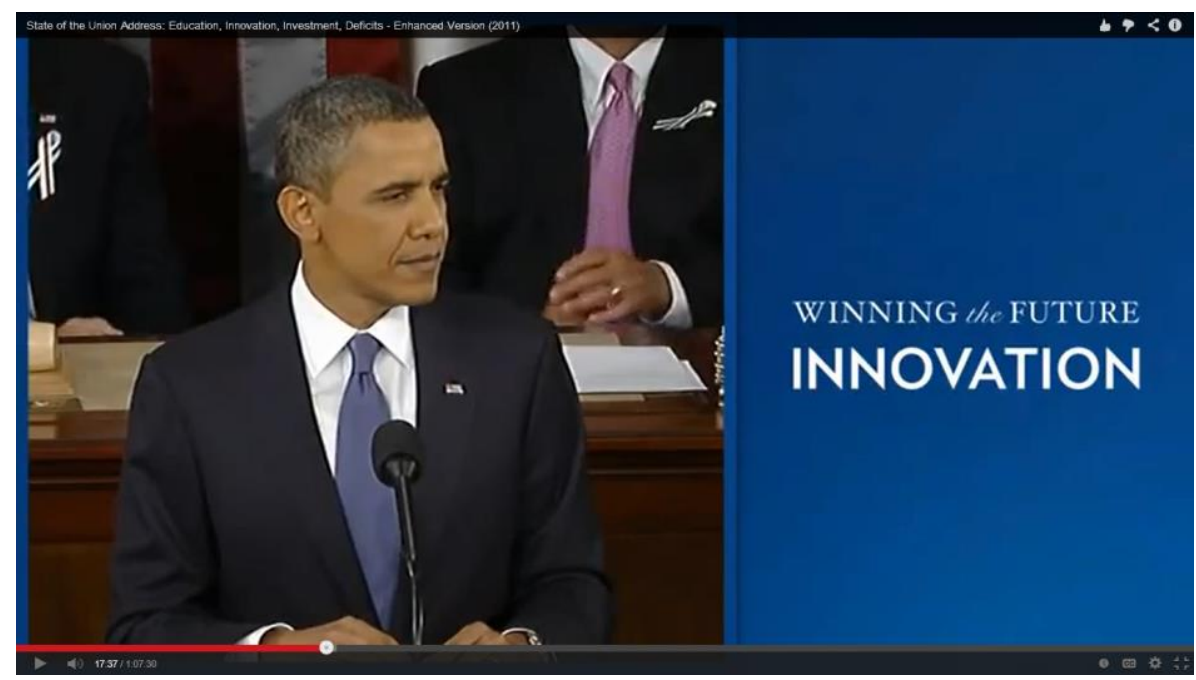

Figure 5: Screen Capture of enhanced State of the Union - Obama; "WINNING the FUTURE - INNOVATION"

The viewer's eye, trained to move left to right, top to bottom, moves seamlessly from the nostalgic pull of the classical serif font to the sleek, contemporary boldness of the sans serif font. As Alex Fowkes writes, "Serif typefaces are used to give a feeling of nostalgia, trust, and heritage[,]" whereas "Sans serif typefaces tend to look more modern" (Fowkes, 2014, 179) [.] The typefaces used in the visual design of presentations such as the enhanced State of the Union are an important part of the address' visual rhetoric.

Typefaces make up part of what Charles Kostelnick describes as the rhetoricity of design:

Design is inherently rhetorical because its forms are largely negotiated and shared by groups of users, or visual discourse communities... By socially constructing design forms, visual discourse communities create, codify, and perpetuate conventional practices, which engender expectations among its members. Those processes occur with all forms of visual language - from architecture... to information design, including typography (left justification, boldface for emphasis), screen design (icons, pull-down menus), pictures (perspective, cross-sectional views), and data displays (pie charts, line graphs) (Kostelnick, 2004, 218-219). 
While these subtle design features may not be obvious elements of the visual rhetoric, it is precisely their innocuous nature that makes them particularly salient modes of aesthetic ideological coordination. Aesthetics operates by conducting the senses and through affective modes of coordination. If aesthetics did not frequently function at the level of background affect, aesthetic regimes would not be capable of so seamlessly orienting relationships to reality. As Kostelnick writes:

Visual language... embodies another form of cultural knowledge - aesthetics... However, the role of aesthetics may seem invisible because both readers and designers may be so entrenched in a given design style that they become oblivious to its influence over them. However, aesthetics permeates all areas of functional design, leaving a trail of cultural tracks (Kostelnick, 2004, 234235).

These design elements of the enhanced State of the Union, from the typeface used to outline and detail the speech, to the graphs and charts used to display data, to the design of the screen and interface itself, all constitute part of the aesthetic operation of the enhanced State of the Union.

The aesthetic labor of the enhanced State of the Union occurs on multiple levels. There is an aesthetics in the sound of Obama's voice: its movement and tempo, its timbre and tone. There is an aesthetics in the construction of the speech: its transition between tenses, its content, and its organization. There is also a whole array of visual aesthetics, from the way the President looks to the way the camera pans between him and the audience. There is an aesthetic relay between sound and image as the President's speech tells the real stories of persons who are displayed sitting in the audience. There are also the visual design elements I outlined above. The presentation of data and graphs labor toward an aesthetics of objectivity and neutrality. The presentation of iconic images creates an aesthetics of nostalgia. The transition to the presentation of images of the President in futuristic settings moves the viewer from this iconic nostalgia towards the progression of futurity, a move also reflected in the transition from serif fonts to sans serif fonts.

The mere fact of experiencing the enhanced version online is also itself an aesthetic experience. The ability to pause, re-wind, and watch at their own leisure gives the viewer a sense of control over their relationship to the political. The interactivity offered by the enhanced version may make the viewer feel as if they are a part of the process. The addition of images, charts, and graphs captures 
the attention of the viewer in multiple ways, mimicking the perpetually mediated digital environment they find themselves in. The very fact that the viewer is treated to this new way of experiencing the State of the Union is itself an aesthetic adjustment offered by the Obama administration for the first time.

A number of contextual factors produce the need for this new aesthetic mode of delivering the State of the Union. The generic requirements of the State of the Union call on the President to outline their legislative agenda. As such, the State of the Union is one of the lengthier and most policy driven speeches that U.S. audiences are called on to observe. This occasion has always presented Presidents with a unique challenge to keep the audience's attention. As Karlyn Kohrs Campbell and Kathleen Hall Jamieson write, "The electronic media have shortened the average American's attention span, with the result that orally delivered presidential speeches are expected to fall within the half-hour limit of shorter television programs, a length that makes it extremely difficult to develop and justify major policy proposals" (Campbell and Jamieson, 2008, 159). Even before the age of the internet, the State of the Union stretched the attention of the average television viewer beyond its breaking point. Yet in this postmodern era of quotidian digital mediation, the President competes for attention not just with the televisual entertainment complex but with the ubiquitous and ever expanding digital information landscape. The population is barraged by a permanent array of digitally mediated information - signals, sounds, memes, tweets, pokes, snapchats, friend requests, buzzfeed lists, and so on, ad infinitum. The enhanced version of the address is a way to stimulate the viewer into a more proactive relationship with the President's speech. It provides new means for capturing the viewer's attention by conforming to the generic expectations of the digitally mediated age.

A perhaps even more important contextual factor making this new mode of aesthetic presentation necessary is the retreat of the political under neoliberalism and the fraying of the fantasy that the political scene can return on our investments in an image of the good life. The aesthetic modality produced by experiencing the enhanced State of the Union is itself a way of suturing nostalgic political attachments to the futurity of political investment. The classical political scene, represented in the traditional rhetorical form of presidential public address, is given new life in the futurity of the digital sphere. The aura of the political is reproduced through an adjusted relationship to public address, a recalibration of the State of the Union's mode of aesthetic presentation. The enhanced State of the Union's aesthetics labors to tell the viewer that the 
political has not disappeared, or retreated - that despite the failures of the political system to protect the security of the American Dream and the mythic promise of economic security to all Americans, they can still feel the political in new and exciting ways.

\section{Nostalgic Cruelty and the The Optimism of Adjustment}

The enhanced version of the State of the Union is a labor of cruel optimism. It returns the viewer to the site of a deflated political scene by reinvesting it with new affective energies and attachments. The recalibrations are not only adjustments in terms of legislative agenda - pseudo-progressive tinkering with the dials of neoliberal control to make the free market system work better for Americans but adjustments in the sense and sensibility of political attachments, that call on viewers to recalibrate their relationship to the political scene. Cruel optimism is primarily a means of temporal adjustment. Restorative nostalgia is one of its primary modalities for returning subjects to the promise of the good life that one finds in a return to origins and ideals.

But cruel optimism cannot rely on restorative nostalgia alone. To rely exclusively on restorative nostalgia would be to dwell in the past, offering no hope for reflective optimism in the future. Cruel optimism requires a movement between a nostalgic longing for the past and an optimistic reflection on a future capable of delivering on the promises that past provides. It requires a recalibration in affective energies, an adjustment in temporalities. The repetition of iconic images of a past long-gone are not simply rehearsed for their own sake, but rather as sites of affective investment for democratic energy in the present, directed toward an optimistic future that appears in spite of the fraying fantasies produced by permanent precarity. Recalibrative nostalgia returns to the ideals and icons of the past to make potent the promise for progression in the future. Without the rhetorical labor of those memories, there is no reason to return to the pact of free market economics that had previously left us abandoned.

I have sought to intervene not only in rhetorical debates surrounding the role of temporality in political speech, but also in scholarly conversations about the aesthetic function of visual rhetoric in presidential address. As Keith V. Erickson forcefully declares, "Presidential rhetoric has taken a visual turn" (Erickson, 2008,358 ). Yet the consequences of this visual turn have not yet been fully explored. Erickson's approach to the visual turn in 
presidential rhetoric reflects the binary temporal dichotomization in rhetorical scholarship between conservative evasion of deliberation about the future and progressive embrace of deliberation about the future. Erickson critiques the visual turn in presidential rhetoric for its ideological transcendence of the public's deliberative function, writing, "Mediated presidential performances are capable of hoodwinking the public, mystifying presidential behavior, lessening an administration's accountability, suppressing the public's participation in politics, and reifying ideological authority figures" (Erickson, 2008, 358). What reading the enhanced State of the Union through Sharma's concept of neoliberal recalibration and Berlant's concept of precarious adjustment tells us is that the function of visual rhetoric need not efface or suppress the public's participation in politics in order to attach the public to a cruel political scene. Instead, it is precisely through the public's optimistic participation in this political scene, their ability to feel political by seeing themselves in the machinations of political speech that the reattachment and recalibration of cruelty occurs.

The 2011 enhanced version of the State of the Union Address offers a case study for understanding the complex relationship between visual rhetoric, time, and presidential speech. By laboring under a recalibrative nostalgia, the enhanced State of the Union allows for modes of political adjustment that return the viewer to the promise of America's exceptional democratic experiment in order to invest their energies in the continuation of that experiment into the future. By accompanying Obama's hopeful rhetorical appeals with a mode of aesthetic experience that allows the viewer to feel the intimacy of political attachment, the enhanced State of the Union revitalizes the political scene of neoliberalism. Yet, by relying on the interface of viewer's body to create this affective and aesthetic experience, the enhanced State of the Union points toward the uncertainty and unpredictability of the political, the livewire through which political rupture may yet disturb the modes of cruel optimism that constitute the lifeblood of neoliberal subjectivity.

Copyright (C) 2015 James Alexander McVey 


\section{Reference List}

Berlant, L. Cruel Optimism. Durham: Duke University Press, 2011. http://dx.doi.org/10.1215/9780822394716

Boym, S. "Nostalgia and Its Discontents." The Hedgehog Review (Summer 2007): 7-18.

Condit, C. M. “Nixon's 'Fund': Time as Ideological Resource in the 'Checkers' Speech.” In Leff, M. C. and F. J. Kauffeld (Eds.) Texts in Context: Critical Dialogues on Significant Episodes in American Political Rhetoric. (Pp. 101-112). Davis, CA: Hermagoras Press, 1989.

Erickson, K. V. "Presidential Rhetoric's Visual Turn: Performance Fragments and the Politics of Illusionism." In Olson, L. C, C. A. Finnegan, and D. S. Hope (Eds.) Visual Rhetoric: A Reader in Communication and American Culture. (Pp. 357-373). Los Angeles, CA: Sage, 2008.

Fowkes, A. Drawing Type: An Introduction to Illustrating Letterforms. Beverly, MA: Rockport Publishers, 2014.

Campbell, K. K. and K. H. Jamieson. Presidents Creating the Presidency: Deeds Done in Words. Chicago, IL: University of Chicago Press, 2008.

Kostelnick, C. "Melting-Pot Ideology, Modernist Aesthetics, and the Emergence of Graphical Conventions: The Statistical Atlases of the United States, 1874-1925." In Hill, C. A. and M. Helmers (Eds.) Defining Visual Rhetorics. (Pp. 215-242). Mahwah, NJ: Lawrence Erlbaum Associates, 2004.

Loehwing, M. "Homelessness as the Unforgiving Minute of the Present: The Rhetorical Tenses of Democratic Citizenship." Quarterly Journal of Speech 96.4 (2010): 380-403. http://dx.doi.org/10.1080/00335630.2010.521171

Murphy, J. M. "Power and Authority in a Postmodern Presidency." In Aune, J. A. and M. J. Medhurst (Eds.) The Prospect of Presidential Rhetoric. (Pp. 28-45). College Station, TX: Texas A\&M University Press, 2008.

Obama, B. "The 2011 State of the Union Address: Enhanced Version." (January 26, 2011): http://www.whitehouse.gov/photos-andvideo/video/2011/01/25/2011-state-union-addressenhanced-version, accessed 4/24/14. 
Riley, R. L. The Presidency and the Politics of Racial Inequality: Nation-keeping from 1831 to 1965. New York, NY: Columbia University Press, 1999.

Sharma, S. "The Biopolitical Economy of Time." Journal of Communication Inquiry 35, no. 4 (2011): 439-444. http://dx.doi.org/10.1177/0196859911417999 